\title{
Income Smoothing Behavior: A Study of Companies Listed at Food and Beverage Sector Companies at Indonesian Stock Exchange
}

\author{
Maropen R. Simbolon, Francis M. Hutabarat and Richard F. Simbolon \\ Universitas Advent Indonesia
}

\begin{abstract}
Income smoothing, or the so-called income smoothing steps management purposed to make the company's reported accounting earnings smooth or with low fluctuation. This behavior was motivated by the existence of market behavior that tends to be responding positively to the knowledge about the company's improved fundamentals and definite properties. This phenomenon was used by management to provide for the welfare of its shareholders as indirectly seen in agency theory. The purpose of this study was to obtain empirical evidence of the influences of the fundamental values that drive management to perform income smoothing. By making observations of selected Consumer Sector companies' data were analyzed using logistic regression. Based on the analysis, the income smoothing behavior and factors that affected it whether it is significantly affect it or not and whether the influence towards the income smoothing practices are positive or negative as seen in companies listed in Indonesia Stock Exchange in the observation period.
\end{abstract}

Keywords: income smoothing behavior 